\title{
Molecular gastronomy is a scientific discipline, and note by note cuisine is the next culinary trend
}

Hervé This ${ }^{1,2}$

\begin{abstract}
For the past two decades, there has been much confusion about molecular gastronomy. This confusion has arisen because people ignore that the word gastronomy does not mean cuisine, it means knowledge about food. Similar to 'molecular biology', molecular gastronomy is a scientific discipline that looks for the mechanisms of phenomena occurring during dish preparation and consumption. As with any other scientific discipline, it can have many applications. One of the first was 'molecular cuisine' but since 1994, 'note by note cuisine' has also been promoted. The latter involves preparing dishes using pure compounds, or more practically mixture of compounds obtained by fractioning plant or animal tissues, instead of using these tissues themselves. Note by note cuisine raises issues in various fields: science, technology, nutrition, physiology, toxicology and politics.
\end{abstract}

Keywords: Cuisine, Molecular cuisine, Molecular gastronomy, Note by note cuisine

\section{Molecular gastronomy}

In 1988, a new scientific discipline, molecular gastronomy, was defined as looking for the mechanisms of phenomena occurring during dish preparation and consumption' $[1,2]$. This new definition presented the opportunity to discuss the precise content of molecular gastronomy and its relationship with other existing fields of science.

There has always been much confusion between science and technology when it comes to food, including over exactly what food is. Dictionaries give the definition: 'any substance that can give to living beings the elements necessary for their growth or for their preservation' [3]. However, one has to recognize that human beings very seldom eat non-transformed tissues or natural products; raw materials are transformed so that chemical and physical changes determine the final composition of all food as well as its 'bioactivity', a term which we propose to describe the sensory effects,

Correspondence: herve.this@agroparistech.fr

${ }^{1}$ INRA, UMR 1145, Group of Molecular Gastronomy, 16 Rue Claude Bernard, Paris 75005, France

${ }^{2}$ AgroParisTech, UFR de Chimie Analytique, 16 Rue Claude Bernard, Paris 75005, France nutritional value, eventual toxic effects, and so on, of the various compounds released by food systems [4].

During food preparation, plant or animal tissues are at least washed and cut, and most food are thermally processed. For example, even for a simple carrot salad, which requires no thermal processing, there is a big difference between the raw product in the field and what is consumed - that is, grated carrots on a plate: this is because cutting the tissue triggers enzymatic reactions [5] and because compounds get transferred between the dressing and the plant tissue [6]. This analysis leads to the conclusion that reagents and products of 'culinary transformations' (transformations performed in the kitchen) should not both be called food. The specific transformation occurring from the raw materials to the final prepared dish is worth studying, both for scientific and technological reasons.

Making the difference between science and technology clear is particularly important for molecular gastronomy because of the confusion between science and cooking (see, for example [7]), and because the public unduly fears 'chemistry in the plate' (this will prove important for the future development of note by note cuisine, described below). The French chemist, Antoine-Laurent de Lavoisier, was right when, in his article about meat 
stocks [8], he wrote that the two fields of science and technology 'do not meet'. The French chemist and biologist Louis Pasteur, who was so successful in both science and technology, was also fiercely opposed to the expression applied sciences [9]. We believe that there is an important difference between the science and the technology of food transformations [10]. The latter is not comparable to the scientific study of the phenomena occurring during dish preparation and consumption, that is, molecular gastronomy. Let us add that phrases such as 'culinary science' or 'science of cooking' [11] are wrong, strictly speaking, unless science here means knowledge in general. Also, there are no 'scientific chefs', contrary to what is too often encountered in the media [12]. Of course the discipline of molecular gastronomy had precedent [13], and many chemical or physical phenomena occurring during dish preparation and consumption were studied before 1988 [14]. However, food science in the 1980s neglected culinary processes. For example, textbooks such as the classic Food Chemistry contained almost nothing on culinary transformations (this is still the case in the most recent edition) [15], with less than $0.5 \%$ of the important chapter on meat dedicated to culinary transformations (for example, meat shrinkage during heating because of collagen denaturation); most of the chapter described raw meat composition and structure, or industrial products (sausages, meat extracts, and so on). The same textbook contained nothing about the effect of thermal processing on wine, despite the widespread use of cooked wine in culinary activity ( $48 \%$ of French classical sauces contain wine; J Henne, MB France, K Belkhir and HT, submitted work).

The complexity of culinary transformations and the general lack of funding by the food industry for studies outside of its field were probably responsible for food science drifting slowly toward the science of ingredients and food technology, neglecting the phenomena that occur when cooking cassoulet, goulash, hollandaise sauce, and so on. It was considered an eccentricity when a paper on béarnaise sauce was published in a scientific journal in the 1970s [16]. This lack of interest in culinary transformations is why the late Nicholas Kurti (1908 to 1998) [17], former professor of physics in Oxford, and I decided in March 1988 that a new discipline had to be introduced [2].

The situation at that time in food science was more or less the same as it had been for molecular biology some decades before. The term molecular biology was first used by Warren Weaver in 1938 to describe certain programs funded by the Rockefeller Foundation, where it simply meant the application of techniques developed in the physical sciences to investigate life processes [18]. The first scientific practitioner to call his work 'molecular biology' was William Astbury, who used the term before 1950 to mean the study of structures, functions, and genesis of biological molecules [19]. What Kurti and I had in mind was more or less the same, but concerning another field of knowledge, so the name molecular and physical gastronomy was chosen.

The choice of 'gastronomy' in this title was obvious: it does not mean haute cuisine but rather 'intelligent knowledge of whatever concerns man's nourishment' [20]. When Kurti died in 1998, the name was abbreviated to molecular gastronomy, and Kurti's name was given to the international meetings of the discipline.

The appeal of this new field was and remains scientifically clear: if one wants to discover new phenomena, the exploration of a new field is a safe bet, as there is plenty of easy exploration. As always, when new knowledge is produced, it is possible to make technological applications. Since 2000, innovations based on molecular gastronomy have been introduced almost every month (frequently, names of famous chemists of the past are given to new kinds of dishes) [21].

However, the initial program of this discipline was inappropriate because it mixed science and technology. In 2000 [22], it was realized that any recipe has three parts: a technically useless part, a 'definition', and 'technical added information'. This last term describes information that is not absolutely necessary to make the dish (old wives tales, proverbs, tips, methods, and so on) [23]. Some years later, it was realized that the appreciation of a dish by an individual is a question of art, not of technique; thus, cooking involves an artistic activity of fundamental importance. At the same time, it was understood that social context is also very important: a dish is not "good" if it is thrown in the face of the guests. All these facts led to the proposal of new program for molecular gastronomy:

1. to scientifically explore 'culinary definitions';

2. to collect and test technical added information;

3. to scientifically explore the art aspect of cooking;

4. to scientifically explore the social aspect of cooking [24].

\section{Application in the kitchen}

At the time that molecular gastronomy was introduced, we and others wanted to modernize culinary practices using what was done in scientific disciplines such as chemistry, physics or biology [25]. The idea to modernize techniques has come up many times in the history of cuisine. In 1969, Kurti [26] mentions the application of physical techniques and, since the beginning of the 1980s, I proposed the use of chemical tools [27]. The name molecular cuisine (or molecular cooking) was given in 1999, at the start of a FP5 European program called INICON. The definition of molecular cuisine is 
'producing food using "new" tools, ingredients, methods' [28].

In this definition, the word new stands for what was not available in kitchens of the western countries in 1980. New tools could include siphons, used to make foams; ultrasonic probes, used to make emulsions; controlled heaters or circulators, used for cooking at temperatures lower than $100^{\circ} \mathrm{C}$; liquid nitrogen, to make sorbets and many other innovative preparations; rotary evaporators and distillators, used to recover extracts; and many other types of laboratory equipment that can have useful applications in the kitchen. Concerning ingredients, many additives were no found in western kitchens of the 80 's, but proved to have useful culinary applications: sodium alginate to make objects with a gellified skin and a liquid core, or spaghetti made of vegetables, and so on; other gelling agents, such as agar-agar or carrageenans; various colors; odorant compounds; and so on. Of course, not all of these items are completely new, other gelling agents from algae have been used in Asia for thousands of years, and many of these tools are used daily in chemistry laboratories, but they were not used by western chefs, and the goal was to modernize the technical component of cooking.

With regards new methods, a wealth of innovative preparations were introduced (and frequently given the name of scientists from the past), such as chocolate chantilly, beaumés, gibbs, nollet, liebig, gay-lussac, braconnot or vauquelins [21].

The term molecular cuisine was sometimes criticized, but the reasons for using it were that innovative cuisine had to be distinguished from science, and in particular from molecular gastronomy. The arguments over the name are unlikely to matter as the term molecular cuisine is likely to die out with the adoption of new techniques. A new idea is now being introduced with the name note by note cuisine [29].

\section{The next culinary trend: note by note cuisine!}

Note by note cuisine was first proposed in 1994 (in the magazine Scientific American [25]) at a time when I started using compounds in drinks and dishes, such as paraethylphenol in wines and whiskeys; 1-octen-3-ol in sauces for meat; limonene; tartaric acid; and ascorbic acid among others. The initial proposal was to improve food, but surely an obvious next step was to make dishes entirely from compounds.

To put it differently, note by note cuisine does not use meat, fish, vegetable or fruits to make dishes, but instead uses compounds, either pure compounds or mixtures. An analogy would be in the way that electronic music is not made using trumpets or violins, but using pure waves that are mixed in to sounds and music. For the various parts of the dish in note by note cuisine, the cook has to design the shapes, the colors, the tastes, the odors, the temperatures, the trigeminal stimulation, the textures, the nutritional aspects and more [30].

The feasibility of this new cuisine has already been shown. On 24 April 2009, the French chef Pierre Gagnaire (who has restaurants in a dozen cities of the world: Paris, London, Las Vegas, Tokyo, Dubai, Hong Kong...) showed the first note by note dish to the international press in Hong Kong. Then, in May 2010, two note by note dishes were shown by the Alsatian chefs Hubert Maetz and Aline Kuentz at the French-Japanese Scientific Meeting in Strasbourg [31]. However the first note by note meal was not served until October 2010, by chefs of the Cordon Bleu School in Paris, to the participants of the 2010 courses at the Institute for Advanced Studies in Gastronomy [32]. On 26 January 2011, at a banquet before the launching event of the International Year of Chemistry at the United Nations Educational, Scientific and Cultural Organization, Paris, a whole note by note meal for about 150 people was served by Potel et Chabot Catering Company [33]. This meal was again served in April 2011 to about 500 chefs receiving Michelin stars in Paris. And since the number of note by note initiatives is becoming too big to be tracked.

\section{Issues}

Many people are worried by note by note cuisine, asking questions about nutrition, toxicology, feasibility, economics and politics. What about nutriments, oligo-elements, vitamins? Are the compounds dangerous? Will food be liquid? Will agriculture become extinct through such a new way of cooking? All kinds of arguments are used to justify why 'traditional food', the cassoulets, stews, choucroute, should be kept. Indeed the question is important, and note by note cuisine will succeed only if we tackle the 'food neophobia' of the human species [34]: this reflex, also experienced by other nonhuman primates, leads individuals to assume that the food they learned to eat when young is 'good', and to fear new food. Our human brain, instead of making us reject novel food as nonhuman primates would do, leads us to negate new dishes and to legitimate old ones. This occurs even when the 'virtues' of the traditional food stuffs are not demonstrated [35], the worst justification being that these food types must be safe because they are old. This is a poor argument; compare this with smoked products, a traditional cooking method, that epidemiologists now clearly see the danger of through the high incidence of cancers of the digestive tract in populations in the north of Europe, who consume a lot of smoked products [36].

Food neophobia is not a good reason to discount the interest of note by note cuisine. Why should we drop traditional cuisine, and adopt note by note cuisine? 
Indeed the alternative is not compulsory; as for molecular cuisine, we could keep traditional cuisine and add note by note cuisine. Or produce hybrids...

\section{The technical issue}

The feasibility of note by note cuisine no longer needs to be demonstrated because meals have already been produced using this techniques, but we still have to discuss the nature of the compounds used. The culinary world already uses very pure compounds, such as water, sodium chloride, sucrose and gelatine. The lay person often ignores the fact that these compounds were prepared by industry through various extraction processes, purifications and technological modifications (for example, the anti-aggregation compounds added to sucrose) [15].

Many other compounds could be prepared in the same way, such as saccharides, amino acids and glycerides, and indeed the food industry already uses some of them. The food additives industry produces pigments, vitamins, preservatives, gelling or thickening agents and so on. Additives are not currently regulated like food ingredients, but could they not be in the future? Or should the regulation of additives be suppressed, and another very different regulation be introduced?

It is difficult to make dishes from pure compounds, and so, to go back to our music analogy, another way is to make dishes in the same way electronic music is composed $[37,38]$. That is, to enlarge the list of usable compounds by adding simple mixtures such as those that the industry already makes by fractionation of milk or grain. Gelatine, for example, is not pure, in the sense that it is not made of molecules of only one kind: the extraction method used to make gelatine results in large variation in the molecular weight of the polypeptidic chains [39]. Also starch is not pure, as it is made of two main compounds, amyloses and amylopectins. In passing, let us not forget that, because starch is a simple fraction of grain, most traditional pastry techniques can be kept for making note by note cuisine.

Let us come back to the question of 'breaking down' plant or animal tissues to prepare fractions. The industry already extracts polysaccharides, proteins, amino acids, surfactants and other compounds from grain [39]. From milk, the industry recovers amino acids, peptides, proteins and glycerides. Could we not do the same from plant (carrots, apples, turnips...) or animal tissues? Could we not, using the same kind of processes (such as direct or reverse osmosis, cryoconcentration or vacuum distillation), prepare fractions that can be used later for note by note cuisine?

Many technology groups study these questions, and technologists at the Montpellier Institut National de la Recherche Agronomique Centre, for example, have devised techniques based on membrane filtration to recover the total phenolics fraction from grape juice [40]. This fraction is very different depending on the raw material, for example whether the juice is from the Syrah variety, or from Grenache, or Pinot: the diversity of the initial products is not erased by the fractionation process, so that cooks can still play with the 'terroir'.

Now we have discussed the issue of ingredients, we have to consider assembling them into dishes. We should not forget that today's food items are material systems of a colloidal nature [41-43], often with a large proportion of water in them. Many organic compounds are poorly soluble in water, and emulsification is obviously a very important process in note by note cuisine. However it is not the only process; all dispersion techniques will be useful.

During the assembly, the various biological properties of food have to be considered. Of course, the nutritional content is important [44] but it would be a mistake to forget that food has to stimulate the various sensory receptors involved in vision, odor, taste, trigeminal system and temperature [45], for instance: this creates many questions. For example, even if the individual absorption spectrum of some pigments are known, the 'color' of a mixture of such pigments is difficult to predict theoretically [46]. Also, when one mixes odorant compounds in proportions near the detection threshold, unpredictable odors are obtained. Worst still, we do not know what will happen when you mix only two odorant compounds: do they make a 'chord' or a fusion [47]?

For taste, the question is even more difficult to answer, because taste receptors and their substrates are not known [48]; it was discovered only recently (less than ten years ago) that the tongue has receptors for fatty acids with long unsaturated chains [49]. This means that other important discoveries could still be made! In the meantime, one can use citric, malic, tartaric, acetic, ascorbic or lactic acids, or saccharides such as glucose, fructose or lactose, as well as the traditional sucrose but experimental tests will be needed to appreciate the result.

For trigeminal effects, some fresh or pungent compounds are known, such as eugenol (from cloves), menthol (one of its enantiomers only), capsaicin (from chilli), piperin (from pepper), ethanol, sodium bicarbonate and many others [48]. But again the knowledge of receptors could lead to new products.

From the texture point of view, technological work can be done, because more studies are needed on the manufacture of colloidal materials. Making simple emulsions is sometimes considered difficult, but more generally one should not assume that the texturization of formulated products is fully solved, even if we now have surimi and analogous systems. Who will succeed in 
making the consistency of a green apple? Or a pear? Or a strawberry? Not only is there still the question of laboratory prototypes but also of mass production.

As a whole, much remains to be done and many aspects of note by note cuisine remain to be studied by science and by technology. Let us finish this paragraph with an important observation: it would be uninteresting to reproduce already existing food ingredients. As synthesizers can reproduce the sounds of a piano or a violin, note by note cuisine could reproduce wines, carrots or meats ... but why? Except for astronauts who have to travel for long periods, there is probably no value in making what already exists, and it is much more exciting to investigate flavors and dishes that were never envisioned using traditional food ingredients [50].

A simple calculation shows the immensity of what could be discovered. If we assume that the number of traditional food ingredients is about 1,000 and if we assume that a traditional recipe uses 10 ingredients, the number of possibilities is 1,000 to the power of 10 (or $10^{30}$ ). However, if we assume that the number of compounds present in the ingredients is about 1,000, and that the number of compounds that will be used in note by note cuisine is of the order of 100 , then the number of possibilities is about $10^{3000}$. And, in this calculation we have not considered that the concentration of each compound can be adapted, which means that a whole new continent of flavor can be discovered.

\section{Nutritional questions}

Here we should begin by saying that traditional food is not a guaranteed to be healthy: bear in mind that the world faces a pandemia of obesity [51]! Of course, some will criticize the modern diet, but it would be rather more appropriate to observe that the new food environment is not suitable for human beings in their modern way of living. Indeed, the human species has had to face alternating times of plenty and starvation [52], and the science of nutrigenomics is now discovering mechanisms through which the human body can face these conditions [53]. For example, too much to eat does not lead to increased excretion, as we could hope, but instead increased storage in fat tissues.

Let us now consider why note by note cuisine could be interesting from a nutritional standpoint. This question relates to making 'light products'. Does the use of sweeteners lead to overconsumption? Previous studies on this could guide the study of the long-term effects of note by note cuisine.

It is certain that the science of nutrition still has questions to answers regarding the use of vitamins, oligoelements and minor nutriments. It would be a mistake to consider that we know everything regarding these elements in food; as an example, a European study of supplementation with vitamin E (a group of hydrophobic compounds with specific antioxidant properties) had to be stopped because of a higher incidence of death in the group of participants who smoke and were receiving the supplement [54].

\section{Toxicology}

This leads us to now consider the question of toxicology. Here again more studies are needed in particular when low doses of compounds are consumed for a long time. In this field, the scientific potential is huge, as beneficial effects are frequently discovered, such as cytochrome P450 polymorphism or, more recently, gene transfers between bacteria that are hosted by algae and bacteria of the human gut when algae are consumed [55].

A strange such case is estragole, which makes up to more than $50 \%$ of the total composition of the essential oils of tarragon and basil [56]. The hydroxyl derivative of this compound seems to be toxic [57], but the reason why is not understood, and there is no particular incidence of liver cancer in populations consuming a lot of such plants [58].

From a toxicity point of view, note by note cuisine will be no different from traditional cuisine, in which animal and plant tissues were never tested. It is a paradox of modern diet that novel foods are studied more than traditional food, and it is possible that some traditional foods would not be allowed if they were introduced today.

Note by note cuisine can avoid toxicity by simply not using the toxic compounds. For example, we can leave out benzo[a]pyrenes and avoid the toxic myristicin (6-allyl-4methoxy-1,3-benzodioxole) from nutmeg; estragole; glycoalkaloids from potatoes and tomatoes; some glucosinolates from cabbages; some phenolics from plant tissues and so on [59]. The public, however, can continue to do what they want, such as continue to consume barbecued products full of benzo[a]pyrens!

The issues with the regulation of food products will then be analogous to the question of selling liquid nitrogen, ultrasonic probes and rotary evaporators to 'molecular cooks'. The evolution of practices will demand new regulations, as was the case when gas and electricity were introduced into homes. And we accept that there will almost certainly be accidents, not because note by note cuisine is more dangerous than knives or gas, but because the culinary world, as in any community, has its proportion of incautious people, such as a German man who put liquid nitrogen in a closed bottle [60]!

Primarily, what I propose to retain from this discussion is that the scientific and technological questions are considered very differently. It is time to learn about the effect of these compounds on the body. 


\section{Art, first!}

The concept of art is complex but, to keep it simple, I propose that culinary art, as well as painting, music, sculpture, literature and other arts, is aimed at creating emotions [61]. Artists never stopped introducing new ideas into their works, and gourmands are longing for new flavors and new sensations. Note by note cuisine can make them happy, because it can produce a wealth of new possibilities.

Is note by note cuisine difficult? Of course cooks will have to become more familiar with the repertoire of ingredients available to them but as new recipes are introduced it will become more and more easy. Each time we have held a note by note event, cooks had to use compounds that they did not know, and they learned to use these products to make remarkable pieces, with new flavors. Of course, one can hardly describe the flavor of these dishes: how would you describe the color blue to someone who cannot see? Also what to name the dishes was difficult, but perfumery solved the issue: N'5 from Channel, Shalimar, and others.

For all those who are afraid of losing their traditional stew, cassoulet or choucroute, let us say that modern art does not replace old art, but simply adds to it, giving more freedom and more choice. Debussy did not make Mozart or Bach disappear; Picasso or Buffet did not prevent us from admiring Rembrandt or Brueghel. And molecular cuisine did not kill nouvelle cuisine or traditional cuisine. Note by note cuisine will be an artistic addition.

\section{Economy}

What will be the cost of note by note cuisine? Will it be more expensive than current cooking? Here, the issue of energy has to be considered because the next cost increase of energy will perhaps be key to the success of note by note cuisine. Today, to "reduce" wine or bouillon when making a sauce, cooks evaporate primarily water (but lose many odorant compounds as well, because of steam evaporation). If we assume a reduction should be by two thirds, as a professional cook would, a simple calculation shows that the energy consumed is $0.417 \mathrm{kWh}$ [4], which means 0.05 euros per sauce.

The question of energy cost had not been considered in traditional cuisine, where meats are heated to greater than $200^{\circ} \mathrm{C}$ to produce compounds that could be immediately achieved in note by note cuisine, where massproduced compounds could be made at a much lower cost.

In addition, it is not necessary to synthesize all the compounds used by cooks, and frequently they can be extracted from plant material, much as chlorophylls are today. Chemists know that hundreds of chemist-years were necessary to synthesize vitamin B12 [62], so agriculture and extraction remain the most efficient ways in the absence of an efficient chemical method. Note by note can use either synthetized or extracted products, regardless of where they came from.

\section{Political and social questions}

The first tests of note by note cuisine unavoidably created fear, because of the crazy idea that we would be eating 'chemicals'. Here, as for genetically modified organisms for example, political ideas confusingly mixed with other questions in the discussion. Note by note cuisine can be successful only when it is well explained, and if the 'authority argument' is used, as Augustin Parmentier well understood when he served potatoes to the king of France, at a time when the hungry country refused this ingredient [63]. But should we not be afraid that, as for genetically modified organisms, note by note cuisine will have disadvantages for human communities? How would farmers survive when - although unlikely all food is made using note by note? These questions are more than chemists can answer, but they call for the following: as some people make money by producing wine instead of selling grapes, farmers could become richer than they are today when producing plant fractions, instead of selling the raw material.

Finally, when appreciating the value of note by note cuisine, we should not forget that humankind is facing an energy crisis: it is not definite that traditional cuisine is sustainable (it is not!) [59]; the new will always beat the old; breaking down products from agriculture and farming is already normal for milk and wheat [39]; why not carrots and apples? The objections being made to note by note cuisine today are the same made half a century ago against electronic music, and guess what you hear on the radio today? In other words, are we not now in a similar situation to the music industry in 1947, when musicians such as Varèse and others were investigating electronic music[64]?

\section{Competing interests}

The author declares that he has no competing interests.

\section{Acknowledgements}

The author thanks INRA and AgroParisTech for support, Rachel EdwardsStuart, Pierre Gagnaire, Pierre Combris, Gérard Pascal, Jacques Risse, JeanMarie Bourre, Annick Faurion, Jean-Louis Escudier and Robert Anton for fruitful discussions.

Received: 12 July 2012 Accepted: 21 September 2012

Published: 1 January 2013

\section{References}

1. This H: La gastronomie moléculaire. Sciences des aliments 2003, 23(2):187-198.

2. This H: La gastronomie moléculaire et physique. In PhD thesis. Paris: VI University; 1995.

3. Trésor de la langue française ; 2006. electronic version [http://atilf.atilf.fr/tlf. htm], access 01/10/2006.

4. This $\mathrm{H}$ : Solutions are solutions, and gels are almost solutions. Pure App/ Chem., ASAP article. http://dx.doi.org/10.1351/PAC-CON-12-01-01, Published online 2012-09-10. 
5. Zawistowski J, Biliarderis CG, Eskin NAM: Polyphenoloxidase. In Oxidative Enzymes in Food. Edited by Robinson DS, Eskin NAM. London: Elsevier Applied Science; 1991:217-273.

6. Cazor A, This $\mathrm{H}$ : Sucrose, glucose and fructose extraction in aqueous carrot root extracts prepared at different temperatures by means of direct NMR measurements. J Agric Food Chem 2006, 54:4681-4686.

7. See for example this strange "Molecular gastronomy network homepage", that some merchants are doing, using the name of a trendy scientific discipline for their business. http://www. moleculargastronomynetwork.com/recipes.html.

8. De Lavoisier AL: Fuvres Complètes. Paris: Imprimerie Nationale; 1862-1893:t. III, 563-578.

9. Pasteur L: Note sur l'enseignement professionnel, adressée à Victor Duruy, 10 nov. 1863. In Fuvres Completes. Paris: Masson; 1924:187. t.7.

10. This H: Cours de gastronomie moléculaire $N^{\circ} \%$ : Science, technologie, technique (culinaires): quelles relations? Paris: Quae/Belin; 2009.

11. This H: Molecular gastronomy in France. Journal of Culinary Science \& Technology 2011, 9(3):140.

12. Daniel Facen, the scientific chef. http://www.finedininglovers.com/stories/ molecular-cuisine-science-kitchen.

13. This H: Une petite histoire de la gastronomie moléculaire. Papilles (Roanne) 1997, 13:5-14

14. Geoffroy Le Cadet M: Mémoires de l'Académie Royale, Histoire de l'Académie Royale des Sciences, Année MDCCXXX, 312. Amsterdam: Pierre Mortier; 1733.

15. Belitz HD, Grosch W: Food Chemistry. Heidelberg: Springer; 1999

16. Perram CM, Nicolau C, Perram JW: Interparticle forces in multiphase colloid systems: the resurrection of coagulated sauce béarnaise. Nature 1977, 270:572

17. This H: Froid, magnétisme et cuisine: Nicholas Kurti (1908-1998, membre d'honneur de la SFP). Bulletin de la Société fFrançaise de Pphysique 1999, 119(5):24-25.

18. Baltimore D: Nobel Lectures in Molecular Biology 1933-1975. New York: Elsevier; 1977:viii.

19. Weaver WT: Molecular biology, origins of the term. Science 1970, 170:591-592.

20. Brillat-Savarin JA: Meditation III. De la gastronomie. In Molecular Gastronomy, This H. New York: Columbia University Press; 2006.

21. Avec Hervé This: dictons, savoir et gourmandise. http://www.pierregagnaire.com/\#/pg/pierre_et_herve.

22. This H: La gastronomie moléculaire et l'avancement de l'art culinaire. Sciences, Publication de l'Association Française pour l'Avancement des Sciences (AFAS) 1998, 98(7):3.

23. This $\mathrm{H}$ : Cours de gastronomie moléculaire $\mathrm{N}^{2} 2$ : les précisions culinaires. Paris: Belin Litterature et Revues; 2010.

24. This $\mathrm{H}$ : Molecular gastronomy: a scientific look to cooking. In Life Sciences in Transition, Special Issue of the Journal of Molecular Biology. Edited by Halldor S. Cambridge: Elsevier Science Ltd; 2004:150.

25. This H, Kurti N: Physics and chemistry in the kitchen. Sci Am 1994, 270(4):44-50.

26. Kurti N: Friday evening discourse at the Royal Institution: the physicist in the kitchen. Proceedings of the Royal Institution 1969, 42/199:451-467.

27. This H, Kurti N: The cooking chemist. The Chemical Intelligencer 1995, 1:65.

28. Introduction of innovative technologies in modern gastronomy for modernization of cooking. http://www.ist-world.org/ProjectDetails.aspx? Projectld=2df59ae3a55d4c14a67d63e25d73748d.

29. This H: La Gastronomie Moléculaire et ses Applications.: Keynote lecture of the Doctoriales de I'Université de Haute Alsace; 1999.

30. Menu constructivisme culinaire pour Pierre Gagnaire. http://www. Ihotellerie-restauration.fr/journal/restauration/2009-05/Menuconstructivisme-culinaire-pour-Pierre-Gagnaire.htm.

31. Molecular gastronomy and Note by Note cooking. http://www.canalc2.tv/ video.asp?idvideo $=9432$.

32. Menu « note à note » pour le programme de l'institut des Hautes Études du Goût à l'école Le Cordon Bleu Paris. http://www.lcbparis.com/news/ noteanote102011/fr.

33. Centre de Resources Nationales Hôtellerie Restauration: Ça vient d'avoir lieu!. http://www.hotellerie-restauration.ac-versailles.fr/spip.php?article1615.

34. Pliner $\mathrm{P}$, Hobden $\mathrm{K}$ : Development of a scale to measure the trait of food neophobia in humans. Appetite 1992, 19(2):105-120.

35. EFSA Scientific Cooperation (ESCO) Report: EFSA compendium of botanicals that have been reported to contain toxic, addictive, psychotropic or other substances of concern. EFSA Journal 2009, 7(9):281.

36. Ohshima H, Friesen M, Malaveille C, Brouet I, Hautefeuille A, Bartsch H: Formation of direct-acting genotoxic substances in nitrosated smoked fish and meat products: identification of simple phenolic precursors and phenyldiazonium ions as reactive products. Food Chem Toxicol 1989, 27(3):193-203.

37. Institute de Recherche et Coordination Acoustique/Musique. http://www. ircam.fr/recherche.html.

38. Gelatin Manufacturers Institute of America homepage. http://www. gelatin-gmia.com.

39. Lorient D, Linden G: Biochimie agro-industrielle. Paris: Masson; 1994

40. Escudier JL, Bes M, Mikolajczak M, Bouissou D, Samson A: The future of the wine sector. http://www.liendelavigne.org/HOME/ANG/DefaultANG.htm.

41. This $\mathrm{H}$ : Modelling dishes and exploring culinary 'precisions': the two issues of molecular gastronomy. Br J Nutr 2005, 93(4):S139-S146.

42. This H: Formal descriptions for formulation. Int J Pharmaceut 2007, 344(1-2):4-8.

43. This $\mathrm{H}$ : Descriptions formelles, pour penser et pour la formulation. L'Actualité Chimique 2008, 322(8):11-14.

44. Roberfroid M, Coxam V, Delzenne N: Aliments Fonctionnels. Paris: Lavoisier Tec et Doc; 2007.

45. This $H$, Salesse $R$, Gervais R: Gastronomie moléculaire et olfaction In Odorat et goût. Paris: Quae; 2012:439-449.

46. This $\mathrm{H}$ : Apprenons enfin à cuisiner de la couleur! In La Couleur des Aliments, de la Théorie à la Pratique. Jacquot M. Edited by Jacquot M, Fagot P, Voilley A. Paris: Tec et Doc Lavoisier; 2012:431-443.

47. Coureaud G, Gibaud D, Le Berre E, Schaal B, Thomas-Danguin T: Proportion of odorants impacts the configural versus elemental perception of a binary blending mixture in newborn rabbits. Chem Senses 2011, 36(8):693-700.

48. Salesse R, Gervais R: Odorat et goût. Paris: Quae; 2012:439-449.

49. Laugerette F, Passilly-Degrace P, Patris B, Niot I, Montmayeur JP, Besnard P: [CD36, a major landmark on the trail of the taste of fat]. Med Sci 2006, 4(22):357-359.

50. This H: La gastronomie moléculaire. Sciences des Aliments 2003, 23(2):187-198.

51. International Obesity TaskForce: Waiting for a green light for health? IOTF Position Paper. London: IOTF; 2003.

52. Starvation.net homepage. http://www.starvation.net/.

53. Meugnier E, Bossu C, Oliel M, Jeanne S, Michaut A, Sothier S, Brozek J, Rome $\mathrm{S}$, Laville $\mathrm{M}$, Vidal $\mathrm{H}$ : Changes in gene expression in skeletal muscle in response to fat overfeeding in lean men. Obesity 2007, 15(11):2583-2594

54. Yusuf S, Dagenais G, Pogue J, Bosch J, Sleight P: Vitamin E supplementation and cardiovascular events in high-risk patients. The Heart Outcomes Prevention Evaluation Study Investigators, New Eng J Med 2000, 342(3):154-160.

55. Hehemann H, Correc G, Barbeyron T, Helbert W, Czjzek M, Michel G: Transfer of carbohydrate-active enzymes from marine bacteria to Japanese gut microbiota. Nature 2008, 464:908-912.

56. Rietjens M, Martena MJ, Boersma MG, Alink GM, Spiegelenberg W: Molecular mechanisms of toxicity of important food-borne phytotoxins. Mol Nutr Food Res 2005, 49(2):131-158.

57. Anthony A, Caldwell J, Hutt AJ, Smith RL: Metabolism of estragole in rat and mouse and influence of dose size on excretion of the proximate carcinogen 1' hydroxyestragole. Food Chem Toxicol 1987, 25:799-806.

58. Nesslany F, Parent-Massin D, Marzin D: Risk assessment of consumption of methylchavicol and tarragon: the genotoxic potential in vivo and in vitro. Mutat Res 2010, 696(1):1-9.

59. Bruneton J: Plantes Toxiques. Paris: Lavoisier Tec et Doc; 2001.

60. German Heston Blumenthal blows off both hands in liquid nitrogen kitchen accident. http://www.telegraph.co.uk/news/ worldnews/europe/germany/5821433/German-Heston-Blumenthalblows-off-both-hands-in-liquid-nitrogen-kitchen-accident.html. 
61. This H, Gagnaire P: Cooking: The Quintenssential Art. Los Angeles: University of California Press; 2008.

62. Woodward RB: The total synthesis of vitamin B12. Pure Appl Chem 1973, 33(1):145-178.

63. Histoire de Montdidier. http://santerre.baillet.org/communes/montdidier/ v2b/v2b4c02b54.php, last access 6 July 2012.

64. This H: La cuisine note à note en 12 questions souriantes. Paris: Belin; 2012.

doi:10.1186/2044-7248-2-1

Cite this article as: This: Molecular gastronomy is a scientific discipline, and note by note cuisine is the next culinary trend. Flavour 2013 2:1.

\section{Submit your next manuscript to BioMed Central} and take full advantage of:

- Convenient online submission

- Thorough peer review

- No space constraints or color figure charges

- Immediate publication on acceptance

- Inclusion in PubMed, CAS, Scopus and Google Scholar

- Research which is freely available for redistribution 